\title{
Cytotoxicity Assessment of a Poly(methyl methacrylate) Synthesized for the Direct Fabrication of Bone Tissues
}

\author{
Lamia Zuniga Linan ${ }^{1 *}$, Nadson Murilo Nascimento Lima ${ }^{1}$, Carol Benatti ${ }^{1}$, Mariana \\ Xavier $^{1}$, Ana A. Rodrigues ${ }^{1}$, Flavio Manenti ${ }^{2}$, Andre Jardini1, Rubens Maciel Filho ${ }^{1}$, \\ Rovilson Gilioli ${ }^{3}$ \\ ${ }^{1}$ Universidade de Campinas - Departamento de Desenvolvimento de Processos e Produtos, Campinas, São Paulo, \\ Brasil; ' 2 Politecnico di Milano - Dipartamento di Chimica, Materiali ed Engegneria Chimica Giulio Natta, Milano, \\ Lombardia, Italy; ${ }^{3}$ Universidade de Campinas - Centro Multidisciplinar para Investigação Biológica na Área da \\ Ciência em Animais de Laboratório, Campinas, São Paulo, Brasil
}

\begin{abstract}
A cytotoxicity study is performed on a poly(methyl methacrylate) polymer (PMMA) to be used for the fabrication of bone tissue by Rapid Prototyping $(R P)$. The solution polymerization is conducted in a pilot plant reactor using more appropriated reagents in consideration of the medical application. Moreover, the polymer is efficiently handled to avoid the side effect of the monomer, reducing the concentration of this specie to $287,731 \mu \mathrm{g} M M A / \mathrm{kg} P M M A$. The cytotoxicity of the polymer is determined through growth monitoring, adherence and morphology of L-929 cells. Additionally, MTT and LIVE/DEAD tests are performed. The results showed continuous and progressive growth of the cells on the surface of the specimens. Moreover, the material did not influence on the viability of mesenchymal cells and inverted fluorescence microscopy images showed a polyanionic dye calcein well retained in the cells in contact with the PMMA as well as the negative control after 72 hours. Thus, the polymer was efficiently synthesized and handled for the expected demands.
\end{abstract}

Key words: PMMA, synthesis, cytotoxicity, viability, mesenchymal cells.

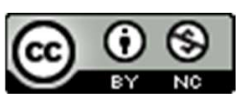

\footnotetext{
*Author for correspondence: lamiazuniga@yahoo.com.mx, lazuli@feq.unicamp.br
} 


\section{INTRODUCTION}

According to the revision of Centro de Gestão de Estudos Estratégicos, CGEE, the world trends in long term (2020-2050) indicates that synthetic, natural and hybrids materials or those synthetized from biotechnological processes will be essential to ensure the quality and efficiency of the service of Brazilian single Health System (SUS) and the Suplementary Health System [1].

Few countries are producing biomaterials because of the strict specifications that these must satisfy to be available for human consumption. Orthopedic prostheses are produced in the Netherlands. Japan and the United States are leaders in the synthesis of biopolymers and biomaterials from chitosan. China, Australia, Canada and South Africa are strong in the manufacture of prostheses from titanium. Brazil imports most of the biomaterials it uses, which represents a high cost for the SUS. On the other hand, according to CGEE, Brazil has the challenge of replacing the traditional cemented joint prosthesis by the cementless one. Thus, there is an important need for technological development in new materials area in order to satisfy the requirements for improvement in the population's health and to decrease the costs of the involved materials.

Poly(methyl methacrylate), PMMA is a widely consumed biomaterial because its properties of biocompatibility and mechanical resistance [2]. The high molecular weight PMMA powder is typically used for manufacturing of bone cement, which is destined to repair bone defects through of an invasive in-situ polymerization process. The cement is an acrylic resin made from a mixture of MMA liquid and the powder of PMMA. The powder includes a prepolymerized PMMA, an initiator that catalyzes the polymerization process and a radiopacifier. Thus, the resin previously prepared at the surgery spot is used as filler for bone cavities and skull defects and also for dental implants and vertebrae stabilization in osteoporosis patients [3]. In [3 - 6], more specific applications of PMMA as bone cement are described

However, the PMMA has a strong potential for direct fabrication of prosthesis by rapid prototyping. Scaffolds of skull cap and femur made from PMMA filament were molding by the Fused Deposition Modeling (FDM) [7], demonstrating this technique allows the construction of complex prosthesis. On the other hand, the use of cemented prosthesis has evinced several drawbacks for the patients and also for the surgeons. The reason is the continued contact with the monomer MMA, whose vapors are toxic and these could be inhaled even though face-masks are worn. Although, it has been reported the cement is not carcinogenic [8].

Additional disadvantages regarding the use of bone cement can be listed: a) Necrosis of the tissues due to heat releases during the polymerization [9]; b) Systemic effects because of the residual monomer, which is released during the first 5 to 10 minutes of polymerization and c) Absorption by the blood of the liquid monomer, which is released within the 15 minutes of polymerization. Conveniently, after curing has been accomplished, any unreacted monomer is trapped within the cement and does not wash out over time because of the low solubility of MMA.

Considering this scenario, the direct fabrication of the prosthesis through Rapid Prototyping (RP) has been envisaged as an innovative alternative that can 
improve the quality of the final product. Therefore, the prosthesis can be built from the powder of the polymer and no addition of the liquid monomer is necessary.

The use of prefabricated prosthesis points to a reduction of $40 \%$ in surgery time and a substantial decrease in the patient's immune response. The reason of this is the lower contact between the patient and the liquid monomer, which is highly irritant.

Prototyping techniques such as Selective Laser Sintering (SLS) or the Fused Deposition Modeling (FDM) are used for this purpose.

Although the properties and characteristics of the PMMA powder to be used for the construction of prosthesis via RP have not yet been standardized, it is known that the polymer must have a high molecular weight in order to achieve the appropriate mechanic properties that are comparable to those of the human body. In general, physical chemistry properties of the PMMA powder used in bone cement include: particle diameter less than $125 \mu \mathrm{m}$; molecular weight from $\left(60,000\right.$ to $\left.1^{\prime} 000,000 \mathrm{~g} / \mathrm{mol}\right)$; density of $1.18 \mathrm{~g} / \mathrm{cm}^{3}$, melting temperature of $160^{\circ} \mathrm{C}$ and glass transition of $105^{\circ} \mathrm{C}$ [10 - 12].

Because of its availability and flexibility in operation, the industrial production of PMMA is widely managed through batch polymerization [13 - 16]. However, because of high exothermic reactions in the process, it is required considerable effort in controller tuning to achieve the proposed objectives [17]. The kinetic of solution polymerization of the MMA follows the free-radical mechanism, which presents nonlinearities and transient behavior. The major source of nonlinearity is the gel-effect that leads to unstable situations, such as excessive temperature rise and rapid increase in polymerization rate [18]. As underlined by [16] and [17], the control of these variables in a process plant is often carried out by manipulating the reaction temperature.

The in-vitro cytotoxicity test measures the effect of chemicals on a culture of cells by the change in total cell protein. The basis of the test is that a cytotoxic chemical, regardless of the site or mechanism of action will interfere with the process of cell division and multiplication even when maintained in culture [19]. The degree of inhibition of growth, related to the concentration of the analyzed specimen, provides an indication of the toxicity.

Toxicity tests conducted on the polymers of PMMA to be used in the medical area are necessary for assessing the purity and quality of the polymer as a function of the residual compounds present in the internal structure of the material.

In this work, we have synthesized a PMMA polymer to be used for fabricating scaffolds by SLS. The polymerization was performed in a pilot-scale laboratory plant by using an alternative combination of synthesis reagents, monomersolvent-initiator (MMA/Ethyl acetate/AIBN), instead of the traditional benzene and toluene as solvent and benzoyl peroxide as the initiator, so as to reduce the risk of rejection by harmfulness and the toxicity of the implant in contact with human tissues. During the process, the reactor temperature was tuned through a Proportional-Integral-Derivative (PID) control algorithm system, in order to reach a molecular weight above 200,000 Daltons. Moreover, 
the polymer was appropriately dried milled and handled before preparing the specimens for the in-vitro tests.

The cytotoxicity of the material was evaluated from both forms qualitative and quantitative. The growth, adherence and morphology of the cell-line NCTC clone 929 (ATCC-CCL-1) was monitored on the surface of the PMMA disks, until an exposure period of 120 hours. Besides, the modified Mosmann's method was used to quantify the proliferation of the mesenchymal stem cells via MTT assay on the first, second and third day of the analysis. Furthermore, the determination of cell viability was made by LIVE/DEAD assay.

The results showed continuous and progressive growth of the cells on the surface of the specimens, which indicates that the synthesized polymer does not disturb the natural cell proliferation.

\section{MATERIAL AND METHODS}

\section{SYNTHESIS OF PMMA}

The solution polymerization of the MMA in the presence of Ethyl Acetate (EA) and Azobisisobutyronitrile (AIBN)/Du-Pont was developed in a batch reactor of a pilot-scale laboratory plant. The reactor was loaded with 10 liters of a mixture composed of $49.27 \% \mathrm{v} / \mathrm{v}$ of MMA, $49.73 \% \mathrm{v} / \mathrm{v}$ of EA and $0.99 \% \mathrm{v} / \mathrm{v}$ of AIBN. Details of the reactor system and specifications of the instrumentations can be found in our previous work [20, 21]. To reach the desired material properties, the process was conducted by tracking a rigorous temperature trajectory in the reactor, which began at $56{ }^{\circ} \mathrm{C}$. By doing so, the polymer (called PMMA-56) was obtained with a specific molecular weight of 213,360 Daltons. After $8 \mathrm{~h}$ of polymerization, the total bulk of the reactor was properly washed with ethanol in order to precipitate the polymer from the solution with EA and to remove the non-polymerized monomer. Then, the polymer was dried and pulverized for the characterization tests.

\section{CHARACTERIZATION AND PREPARING}

The early synthesized polymer was strictly prepared for the cytotoxicity tests. Results of the physicochemical characterization by SEC/GPC and DSC are listed in a previous work [20]. Disks of $25 \mathrm{~mm}$ and $5 \mathrm{~mm}$ diameter and $1 \mathrm{~mm}$ thick were compression molded from the powder of the polymer.

Through a methodological analysis by Multiple Headspace extraction Gas Chromatography (MHS-GC) developed in our previous work [22], the residual monomer presents in the powder of PMMA-56 was quantified. The measurement reported a mass percentage of MMA in the polymer of $0.0288 \%$ (mass of MMA/mass of polymer), which corresponds to a concentration of 287,731 $\mu \mathrm{g}$ MMA/ kg PMMA-56. 
Cytotoxicity assessment of a PMMA biopolymer

\section{CYTOTOXICITY ASSESSMENTS}

Cytotoxicity assessment on cells in culture

Sterilization of the samples.

The PMMA-56 disks, with a diameter of $25 \mathrm{~mm}$, were washed with distilled and deionized water. Then, were sterilized with ethanol $99.5 \%$ p.a. in an ultrasound bath during 15 minutes. Hereafter, the samples were disinfected with $15 \mathrm{ml}$ of Phosphate Buffer Solution (PBS) (containing Potassium Chloride and Potassium Phosphate) and an antibiotic (a mixture of Penicillin G Potassium and Streptomycin Sulfate) during 30 minutes, as suggested in [23]. After that, the disks were transferred to the individual well plates, which have diameter of $35 \mathrm{~mm}$ and a depth of $15 \mathrm{~mm}$.

Subculturing of the cells.

The procedure for culturing the cells was developed according to the instructions in [23]. For this study we used the NCTC clone 929 cells (L cell, L-929, derivate of Strain L), which come from the subcutaneous connective tissue, areolar and adipose of male Musmusculus. The cells have the morphology of fibroblast and adherent growth properties.

Firstly, for removing the inhibitor, the cells were washed with a solution of $0.25 \% \mathrm{p} / \mathrm{v}$ of Trypsin and $0.53 \mathrm{mM}$ of EDTA solution. Then, the dispersion of the cells was observed under the inverted microscope Vanguard TENS $10 \mathrm{~N}$ at $100 \mathrm{X}$ magnification (10X eyepiece magnification and $10 \mathrm{X}$ bright field objective). Generally, the dispersion of the cells occurs within 5 min to $15 \mathrm{~min}$. The next step was the addition of $6.0 \mathrm{ml}$ to $8.0 \mathrm{ml}$ of the culture medium, Fetal Bovine Serum (FBS) to improve the growth of the cells. After that, the cells were maintained in culture in an environment at $37^{\circ} \mathrm{C}$ and $5 \%$ of carbon dioxide $\left(\mathrm{CO}_{2}\right)$ during 72 hours.

Exposing the cells to the test compounds.

The intention of the test is to evaluate the effects of the residual MMA on the division, multiplication and adherence of the cells in culture.

During the culturing time, the cells tend to adhere to the surface of the flasks, thus with the aim of transferring them to the well plates containing the disks of PMMA-56, it is necessary to resuspend the cells in a culturing medium, which contains $10 \% \mathrm{v} / \mathrm{v}$ of bovine fetal serum, $1000 \mathrm{UI} / 1$ of Penicillin G Potassium and $1000 \mu \mathrm{g} / 1$ of Streptomycin Sulfate. According to the experimental protocol in [24], two milliliters of cell suspension, whose final concentration in the culturing medium was $4 \times 10^{5} \mathrm{cell} / \mathrm{ml}$, were placed on the surface of the disks of PMMA-56 to observe their dispersion and growth. In another clean flask, the same amount of suspension was transferred without the polymer material. This system was used as reference.

We developed two studies of toxicity in triplicate where two different batches of the cells NCTC clone 929 were used on each one. 
The set of the analysis, the reference flask and the well plates with PMMA-56 disks were maintained in a heated chamber at $37^{\circ} \mathrm{C}$ and $5 \% \mathrm{v} / \mathrm{v}$ of $\mathrm{CO}_{2}$ environment during a total exposure period of 120 hours.

Microscope observation of the growth and adhesion of the cells on the surface and on the border of the disks were carried out each 24 hours.

\section{MTT assay}

Isolation of the mesenchymal stem cells from adipose tissue.

Human adipose tissue, from liposuction surgery was provided by Professor Paulo Kharmandayan from the Surgery Department of the Faculty of Sciences Medical of University of Campinas (UNICAMP). The material was sterilized according to the particular procedure of the Plastic Surgery Unit of UNICAMP, thus, it was washed with PBS to remove any connective tissue and red blood cells, then it was added to a 50-ml Falcon tube, followed by digestion for 30 min. at $37{ }^{\circ} \mathrm{C}$, with $20 \mathrm{mg}$ collagenase type $1 \mathrm{~A}$ (Sigma), $200 \mathrm{mg}$ of bovine serum albumin (BSA), $20 \mathrm{ml}$ of Dulbecco's Modified Eagle's Medium Low Glucose (DMEM-LG) and $10 \mu \mathrm{l}$ of gentamicin.

After the digestion, $10 \mathrm{ml}$ of PBS was added to neutralize the enzymatic activity, and the cells were centrifuged at $1500 \mathrm{rpm}$ for $15 \mathrm{~min}$, then resuspended in $10 \mathrm{ml}$ of Dulbecco's Modified Eagle's Medium (DMEM) with $10 \%$ PBS, seeded into the culture plate and incubated at $37^{\circ} \mathrm{C}$ with $5 \% \mathrm{v} / \mathrm{v}$ of $\mathrm{CO}_{2}$ during 24 hours.

After the first 24 hours, the medium was changed every three days until the cells reached 70 to $80 \%$ of confluence. After four passages, the Adipose tissuederived stem cells (ADSCs), with a concentration of $1 \times 10^{3}$ cells $/ \mathrm{ml}$ were characterized and seeded into a 96-well plate and incubated with DMEM-LG containing $10 \%$ PBS at $37^{\circ} \mathrm{C}$ for 24 hours.

Incubation of the specimen disks

The $5 \mathrm{~mm}$ diameter disks were incubated with the ADSCs for 24 hours. DMEM-LG containing $0.5 \%$ phenol was used as the positive control for toxicity $(\mathrm{CT}+)$, whereas DMEM-LG containing 10\% PBS was used as the negative control for toxicity (CT-). The cells were cultured for 24, 48 and 72 hours.

The modified MOSMANN method was used for the MTT assay [25]. After the designated incubation time, the disks were removed, and the well plates were washed with $200 \mu 1$ of PBS and $200 \mu 1$ of DMEM-LG. Next, $200 \mu 1$ of thiazolyl blue tetrazolium bromide solution (MTT, Sigma) in DMEM-LG $(0,5 \mathrm{mg} / \mathrm{ml})$ was added, and the plate was incubated in the dark for 4 hours at $37^{\circ} \mathrm{C}$.

The MTT solution was removed, and $200 \mu 1$ of dimethyl sulphoxide (DMSO) was added to determine the absorbance curve at $\lambda=595 \mathrm{~nm}$ in a FilterMaxF5 Multi-Mode Microplate reader (Molecular Probes).

As established in the MTT protocol, each test included a blank containing the complete culture medium without cells and the absorbance values were collected in triplicate for each day of evaluation.

The absorbance values were expressed as optical density (OD). The comparison among the values was carried out by using the Fisher's Least 
Significant Difference (LSD) test, following one-way analysis of variance (ANOVA). Analysis with $\mathrm{p}<0.05$ were considered significant. The StatView software (SAS Institute Inc.) was used for this purpose.

LIVE/DEAD cytotoxicity test

A qualitative test LIVE/DEAD Viability/Cytotoxicity is a mixture with two markers: a green fluorescent marker (Calcein AM) and a red fluorescent marker (Ethidium homodimer-1). The Calcein AM is well retained within live cells, producing an intense uniform green fluorescence (at 495/515 nm excitation/emission). Conversely, Ethidium homodimer-1 penetrates only cells with membrane damage (at 495/635 nm excitation/emission), causing reduction of Calcein AM, when both dyes are present. Thus, when there is an appropriate mixture of the two markers, the cells that have an intact cell membrane (viable) are marked in green fluorescence, while cells that exhibit cell membrane damage (non-viable) are marked in red fluorescent [26].

A Live/Dead fluorescence assay kit (Molecular Probes) was used to qualify the ADSCs viability. The PMMA-56 disks with a $5 \mathrm{~mm}$ diameter were incubated with the ADSCs for 24, 48 and 72 hours, then the cells were washed with 200 $\mu 1$ of PBS and treated with a solution of Calcein AM and Ethidium homodimer1 according to the instructions from the manufacturer.

The ADSCs were incubated at $37{ }^{\circ} \mathrm{C}$ for 30 minutes and then washed and maintained in PBS. These cells were observed by inverted fluorescence microscopy (Nikon E800) with a specific program (Image Pro-Plus software).

\section{RESULTS AND DISCUSSION}

Figures 1 to 3 from a) to c) are100X-magnified images of the cells in the reference flask, on the central surface and on the border of the disk during 24 $\mathrm{h}, 48 \mathrm{~h}$ and $120 \mathrm{~h}$, respectively. The images show the continuous division and multiplication of the cells over time when maintained in culture and in contact with the polymer.

In the first 24 hours, the cells contained in the reference flask (Fig. 1a) and on the disk surface (Fig. 1b) were rounded because of the effect of the initial washing with Trypsin/EDTA solution. This contraction can be noticed by the round and diminutive shape that the cells present on the surface. Additionally, some clustering of the cells is evident because of the initial inactivity; although on some sites of the disk there is a portion of unentanglement cells, which acquired a needle shape (Fig. 1c). This behavior is characteristic on the initial stage of growth.

After 48 hours, cell growth was observed either on the flask surface and on the evaluated disks. This event was characterized by the maximum distension and spreading of the cells on the whole surface, as is showed in Figures $2 a$ ), 2 b) and $2 \mathrm{c}$ ).

Having passed this stage, the cells started acquiring firstly needle shape and rounded after, as a result of interacting with the neighboring cells, which also were growing. Compared with the cells in Figure 1b), the population of cells in the image of the Figure $2 \mathrm{~b}$ ) is larger, also these are distributed forming overlapping layers. On the other hand, it is observed that the distension and 
growth of the cells on the border of the disk is slower than in the centre area for the same culturing time (Fig. $2 \mathrm{c}$ ). This behavior is related to the reduction of the area on the border and a lower quantity of deposited cells since the beginning of the test, which could reduce the growth rate of the cells.

At the end of 120 hours of culture, the maximum cell growth is observed, which occurs in the reference flask (Fig. 3 a), as well as on the center of the disk (Fig. $3 \mathrm{~b}$ ). Also, in Figure $3 \mathrm{c}$ ), the border of the disk reveals the beginning of the overlapping layers as a result of the cell proliferation.

During the development of this study, we observed a rapid a continuous cell growth both on the surface of the PMMA-56 disk and in the reference flask. Thus, it was demonstrated that the cell metabolic activity was not disturbed neither the adopted methodology, nor the residual chemicals contained in the polymer.

In light of the obtained results in this in-vitro cytotoxicity assay, it is relevant to affirm the synthesized material presents no risk of toxicity.

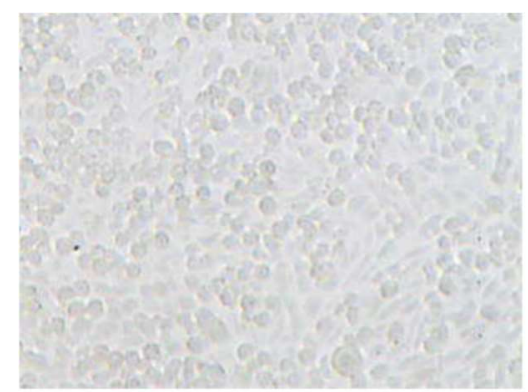

1 a)

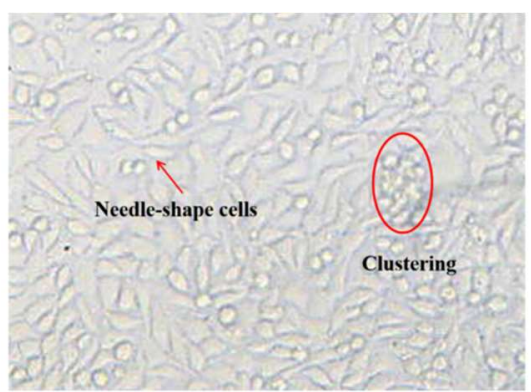

$1 \mathrm{b)}$

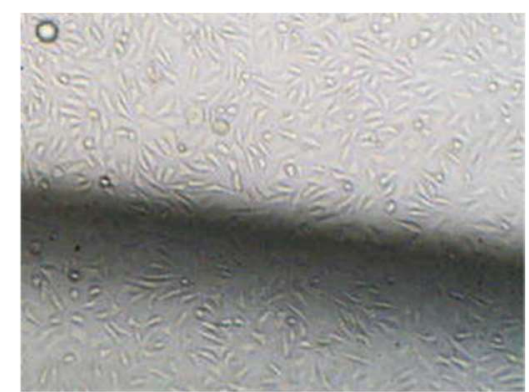

1 c)

Figure 1. Monitoring the cell growth in presence of the test chemicals in an atmosphere with oxygen and $5 \% \mathrm{CO}_{2}$ at $37^{\circ} \mathrm{C}$ at $24 \mathrm{~h} .1 \mathrm{a}$ ) in the reference flask, $1 \mathrm{~b}$ ) on the disk surface, $1 \mathrm{c}$ ) on the border of the disk. Magnification $100 \mathrm{X}$.

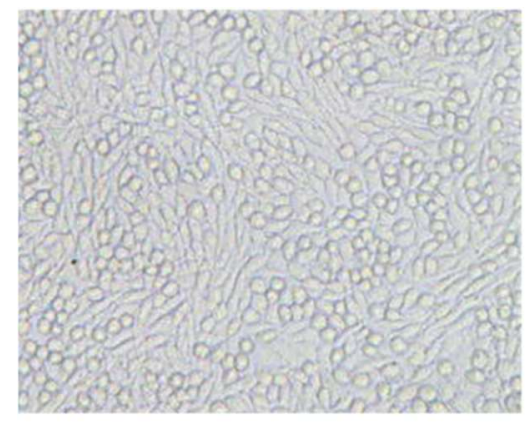

2 a)

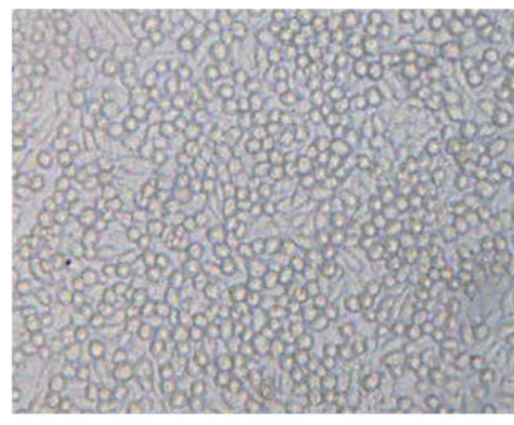

2 b)

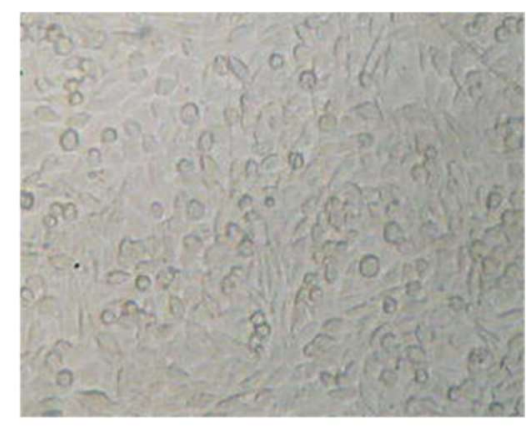

2 c)

Figure 2. Monitoring the cell growth in presence of the test chemicals in an atmosphere with oxygen and $5 \% \mathrm{CO} 2$ at $37{ }^{\circ} \mathrm{C}$ at $48 \mathrm{~h} .2 \mathrm{a}$ ) in the reference flask, $2 \mathrm{~b}$ ) on the disk surface, $2 \mathrm{c}$ ) on the border of the disk. Magnification $100 \mathrm{X}$. 


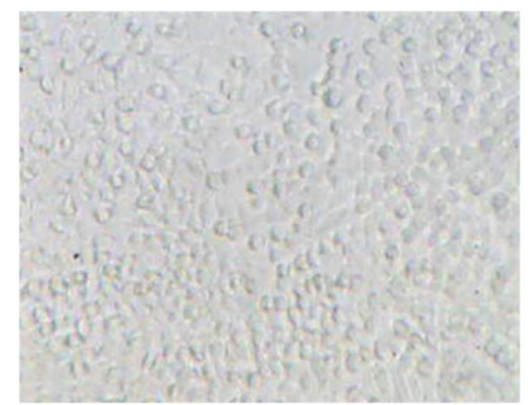

3 a)

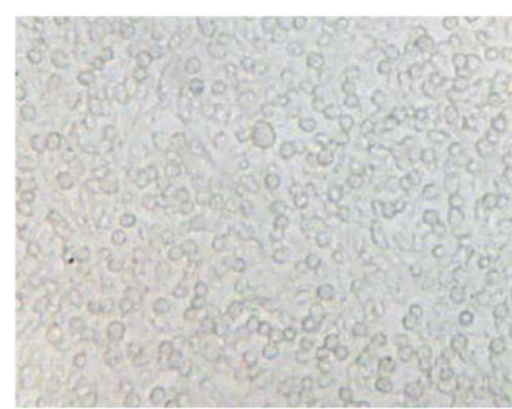

3 b)

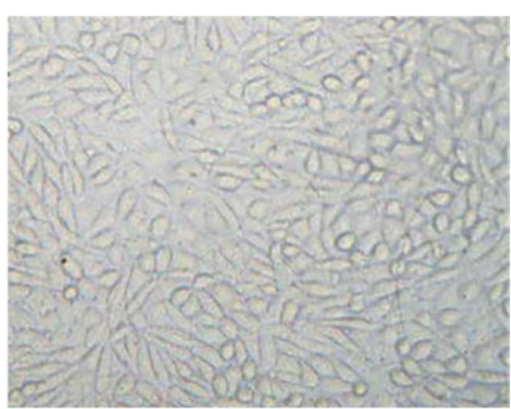

3 c)

Figure 3. Monitoring the cell growth in presence of the test chemicals in an atmosphere with oxygen and $5 \% \mathrm{CO} 2$ at $37^{\circ} \mathrm{C}$ at 120 h. 3 a) in the reference flask, 3 b) on the disk surface, $3 \mathrm{c}$ ) on the border of the disk. Magnification $100 \mathrm{X}$.

Table 1 presents the average optical absorbance values (OA) measured for the negative $\left(\mathrm{OA}_{\mathrm{CT}-}\right)$ and positive $\left(\mathrm{OA}_{\mathrm{CT}+}\right)$ control, for the blank $\left(\mathrm{OA}_{\mathrm{b}}\right)$, for the ADSCs cells in contact to the PMMA-56 (OAPMMA-56) and also the percentage of cell density after an exposure time of 24, 48 and 72 hours. Furthermore, Figure 4 shows the cell density and the percentage of cell density versus the time, in relation to the negative control for the ADSCs cells containing complete culture medium plus the specimen test. Both of the parameters were estimated as follow:

Cell density $=O A_{i}-O A_{b}$

$\%$ Cell density $=\frac{O A_{P M M A}}{O A_{C-}} \times 100$

Where, $i$ is CT-, CT+ or PMMA-56. The obtained results show a progressive increase of the cell density for the CT-control and for the specimen test. Additionally, a higher absorbance rate for the specimen test was registered, especially at 72 hours when the OAPMMA-56 value doubled. This indicates an increase in cell proliferation. The $\mathrm{CT}+$ did not show significant cell density variation during the measuring time, which would indicate reduction of the rate proliferation of the cell, stagnation and cell death.

Furthermore, according to the one-way ANOVA, there are not significant differences between the PMMA-56 and the CT- after 24 and 48 hours of culture. Additionally, after 72 hours, cells cultured with PMMA-56 showed higher proliferation when compared to CT-, considered statistically significant $(\mathrm{p}<0.05)$.

These results show that the PMMA-56 did not affect mesenchymal cell viability after an exposure period of 72 hours; conversely, rapid kinetic growth is evident after 48 hours, which indicates there are no cytotoxic effects of PMMA-56 for cell proliferation. 
Table 1. Average optical absorbance read at $\lambda=595 \mathrm{~nm}$ for the blank, controls and specimen test wells

\begin{tabular}{llllll}
\hline Time $/ \mathrm{h}$ & $\mathrm{OA}_{\mathrm{b}}$ & $\mathrm{OA}_{\mathrm{CT}-}$ & $\mathrm{OA}_{\mathrm{CT}+}$ & $\mathrm{OA}_{\text {PMMA-56 }}$ & \% Cell density \\
\hline 24 & 0.0325 & 0.1101 & 0.0380 & 0.109 & 98.6 \\
48 & 0.0300 & 0.109 & 0.0394 & 0.121 & 116.0 \\
72 & 0.0302 & 0.135 & 0.0377 & 0.220 & 181.0 \\
\hline
\end{tabular}

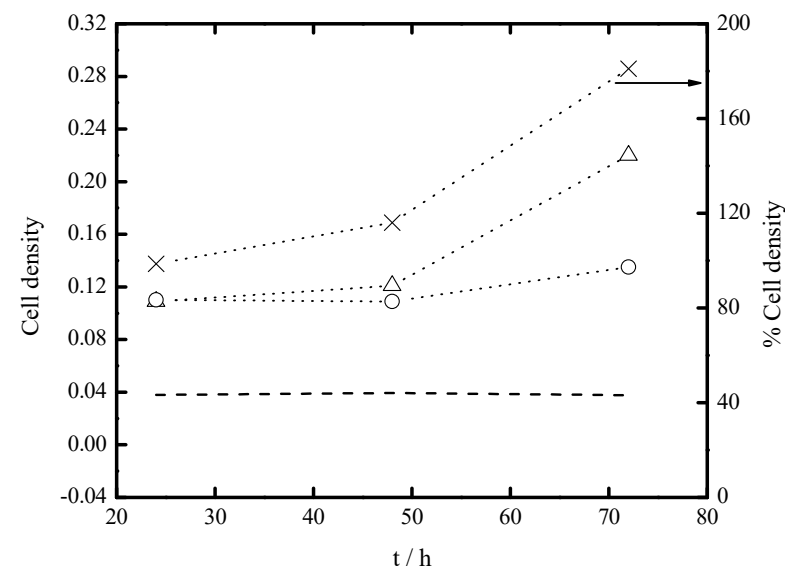

Figure 4. Profiles of cell density and percentage of cell density versus time by MTT assay. Readings for $24 \mathrm{~h}, 48 \mathrm{~h}$ and $72 \mathrm{~h}$ at $\lambda=595 \mathrm{~nm}$ for the controls and for the ADSCs cells in the presence of PMMA-56. ------ CT+, ---O--- CT,--- $\triangle$---PMMA-56, ---X--- \% Cell density.

Figures 5, 6 and 7, from a) to c) show respectively the fluorescence measurements from the inverted microscope for the exposure periods of 24,48 and 72 hours.

After incubation with the solution of Calcein AM and Ethidium homodimer-1, the culture of cells in the presence of the PMMA-56 and in the negative control exhibited living cells. Thus, it is possible notice an intensive and uniform green fluorescence, and intact membrane. A qualitative observation of the images 5 (a) and b), 6 (a) and b) and 7 (a) and b) allow us to affirm that the cell proliferation and morphology of the cells in contact with the PMMA-56 are comparable to those found in the negative control (CT-). As was predicted from the profile for $\mathrm{CT}+$ in the Figure 4, the images $5 \mathrm{c}$ ), $6 \mathrm{c}$ ) and $7 \mathrm{c}$ ) showed cell death at all exposure periods. Also, these evidenced debris and cell fragments, producing a bright red fluorescence.

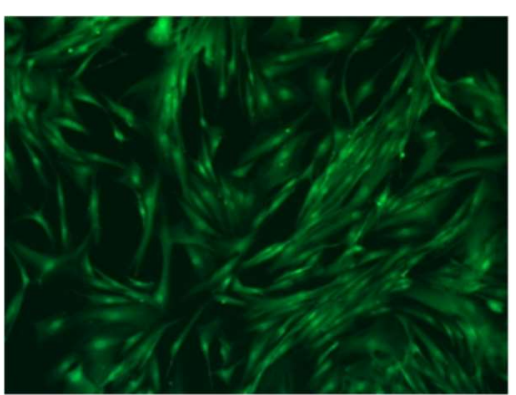

5 a)

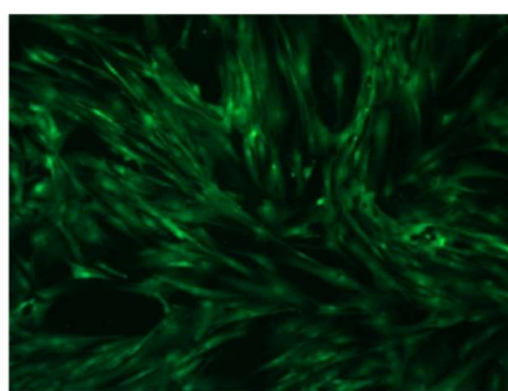

5 b)

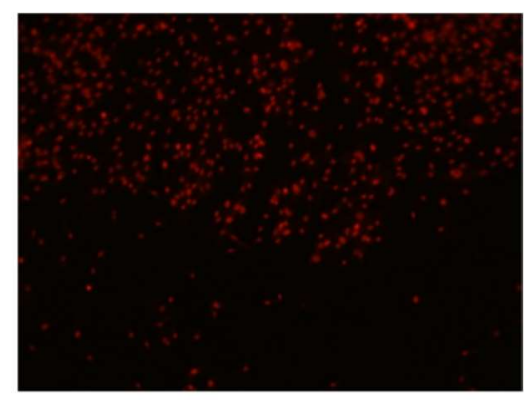

5 c)

Figure 5. Fluorescence images obtained from the LIVE/DEAD assays for the systems in culturing after 24 h. 5 a) is the $\mathrm{CT}-, 5 \mathrm{~b}$ ) is the PMMA-56 and $5 \mathrm{c}$ ) is the CT+ 


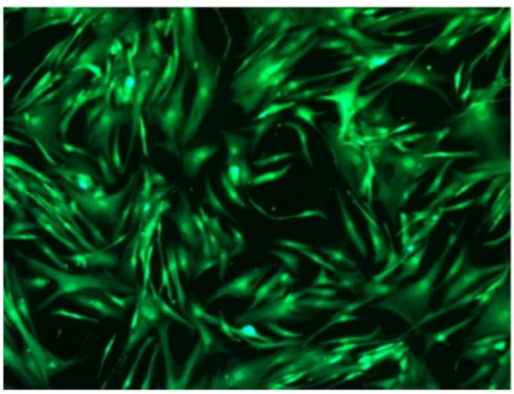

6 a)

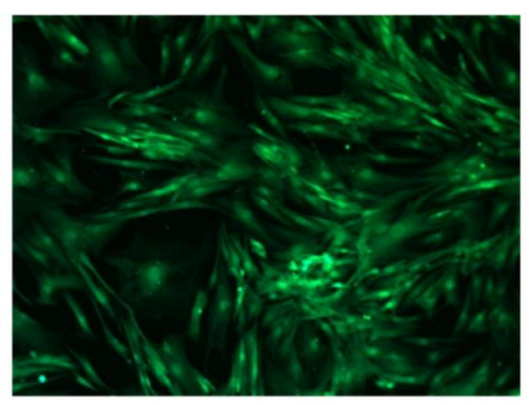

$6 \mathrm{~b})$

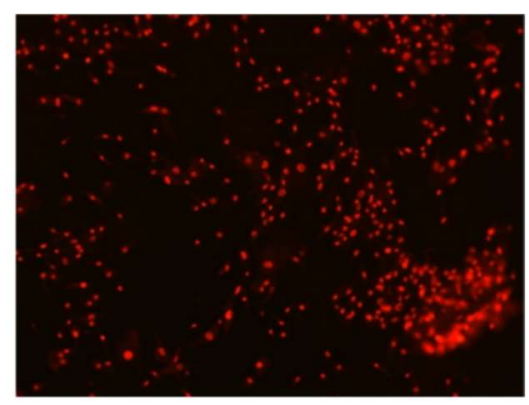

$6 \mathrm{c})$

Figure 6. Fluorescence images obtained from the LIVE/DEAD assays for the systems in culturing after 48 h. 6 a) is the CT-, 6 b) is the PMMA-56 and $6 \mathrm{c}$ ) is the CT+

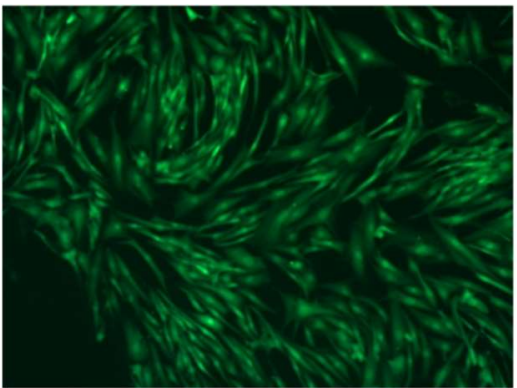

7 a)

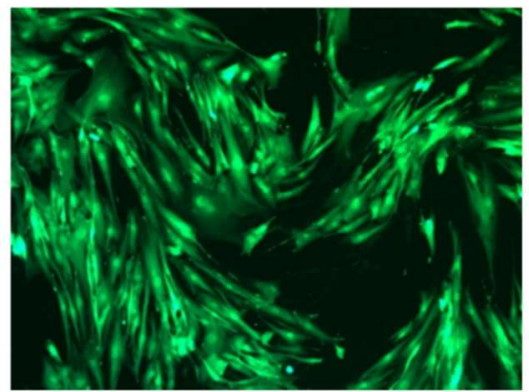

7 b)

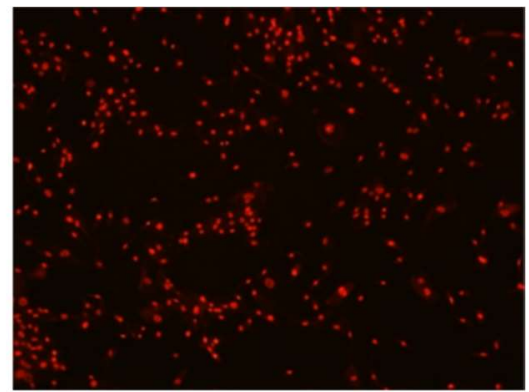

7 c)

Figure 7. Fluorescence images obtained from the LIVE/DEAD assays for the systems in culturing after $72 \mathrm{~h} .7$ a) is the CT-, $7 \mathrm{~b}$ ) is the PMMA-56 and $7 \mathrm{c}$ ) is the CT+

\section{CONCLUSIONS}

Moving forward in the previous developments of the author themselves, as a) the synthesis of a polymer of PMMA intended to meet the direct fabrication of prosthesis through the Selective Laser Sintering and b) the implementation of a drying and purification methodology to remove the residual monomer to a concentration of $0.0288 \%$ by mass, this work reported the results of toxicity tests developed in the polymer under study.

It was found in all stages of the cytotoxicity test, with the NCTC 929 clone cells that the cell activity was evident and progressive, in the culture medium, as well as on the surface of the polymer disks. The LIVE/DEAD assay images showed that the cells in contact with the PMMA-56 were growing naturally without alteration in their morphologies. Additionally, quantitative analysis, by MTT assay, showed us absorbance values that were higher than the negative control, which indicated a progressive increase in cell density and also, a rapid growth rate during the period of examination. This behavior demonstrates that the PMMA-56 did not interfere with the natural processes of cell proliferation. The results in this work showed that having implemented a methodology of syntheses and a suitable preparation, which included washing and vacuum drying, it was possible to decrease the amount of residual chemicals in the polymer to suitable toxicological levels in such a way that these do not represent a biological threat when they are in contact with living tissues. 


\section{ACKNOWLEDGEMENTS}

This work was supported by the São Paulo State Research Support Foundation/Fundação de Amparo à Pesquisa do Estado de São Paulo (FAPESP), Grant numbers 2008/57860-3, 2009/09092-0, 2011/09631-8 and 2010/16952-2. Additionally by the National Counsel of Technological and Scientific Development (CNPq)/INCTBIOFABRIS/FEQ/UNICAMP, Grant number 573661/2008-1.

\section{HUMAN AND ANIMAL RIGHTS}

This work not involved the use of human subjects and animal experiments. The use and manipulation of animal and human cells followed the terms and conditions of Ethic Committee in the Use of Animals of University of Campinas (CEUA-UNICAMP), Law No 11,794/2008 dated October 8, of the Brazilian Society of Science in Laboratory Animals (SBCAL)

\section{REFERENCES}

1. CGEE. Materiais avançados 2010-2012. Centro de Gestão e Estudos Estratégicos (CGEE). Brasília: $\quad 2010.260$. 360 Available in http://www.cgee.org.br/repositorio/biblioteca cgee.html>, Access in 16 sep. 2014.

2. Ratner, B.D., Hoffman A.S. (1996). Biomaterials Science, an Introduction to Materials in Medicine, (Academic Press, San Diego), pp. 165-214.

3. Murakami N, Wakabayashi N, Matsushima R, Kishida A, Igarashi Y, Effect of high-pressure polymerization on mechanical properties of MMA dentature base resin, J Mech Behav Biomed Mater. (2013), 20: 98-104.

4. Frazer RQ, Byron RT, Osborne PB, West KP. PMMA: An essential material in medicine and dentistry. J. Long-term. Eff. med. 2005; 15: 629-639.

5. Garfin SR, Reilley MA. Minimally invasive treatment of osteoporotic vertebral body compression fractures. Spine J. 2002; 2: 76-80.

6. Wardlaw D, Cummings S, Meirhaeghe JV. Efficacy and safety of balloon kyphoplasty compared with non-surgical care for vertebral compression fractures (FREE): a randomised controlled trial. Lancet. 2009; 373: 1016-1024.

7. Espalin D, Arcaute K, Rodriguez D, Medina F. Fused, deposition modeling of patient-specific polymethylmethacrylate implants. Rapid Prototyping J. 2010; 16 (3): 164-173.

8. Lomax LG, Krivanek ND, Frame SR. Chronic inhalation toxicity and oncogenicity of methyl methacrylate in rats and hamsters. Food Chem Toxicol. 1997; 35: 149-159.

9. Di Maio FR, The science of bone cement: a historical review. Orthopedics. 2002; 25: 13991407.

10. Mousa WF, Kobayashi M, Shinzato S, Kamimura M, Neo M, Yoshihara S, et al. Biological and mechanical properties of PMMA-based bioactive bone cements. Biomaterial 2000; 21 : 2137-2146.

11. Bruens ML, Pieterman H, Winjn JR de, Vaandrager JM. Porous polymethylmethacrylate as bone substitute in the craniofacial area. J. Craniofac Surg. 2003; 14: 63-68.

12. Santos JGF, Peixoto LS, Nele M, Melo PA, Pinto JC. Theoretical and experimental investigation of the production of PMMA-based bone cement. Macromol. Symp. 2006; 243: 112.

13. Chang J, Lai J. Computation of optimal temperature policy for molecular weight control in a batch polymerization reactor. Ind. Eng. Chem. Res. 1992; 31: 861-868.

14. Rho H, Huh Y, Rhee H. Application of adaptive model-predictive control to a batch MMA polymerization reactor. Chem Eng Sci. 1998; 53: 3729-3739.

15. Chang J, Liao P. Molecular weight control of a batch polymerization reactor: experimental study. Ind. Eng. Chem. Res. 1999; 38: 144-153.

16. Pahija E, Manenti F, Mujtaba IM. Selecting the best control methodology to improve the efficiency of discontinuous reactors. In: Kraslawski A, Turunen I (Eds). ESCAPE 23European Symposium of Computer Aided Process Engineering: Proceeding of ESCAPE 23, 
European Symposium of Computer Aided Process Engineering; June 9-12, 2013; LappeerantaFinland. Amsterdam: Elsevier, 2013. 805-810.

17. Lima NMN, Zuniga LL, Maciel Filho R, Wolf Maciel MR, Embiruçu M, Grácio F. Modeling and predictive control using fuzzy logic: application for a polymerization system. AICHE J. 2010; 56: 965-978.

18. Antunes AJB, Pereira JAFR, Fileti AMF, Fuzzy control of a PMMA batch reactor: Development and experimental testing. Comput. Chem. Eng. (2005); 30: 268-276.

19. Clothier RH. The frame cytotoxicity test (kenacid blue), In: S. O’Hare, C.K. Atterwill. In vitro toxicity testing protocols. $1^{\text {st }}$ ed. Totowa: Humana Press; 1995. 109-118.

20. Zuniga LL, Lima NMN, Maciel Filho R, Sabino MA, MA, Kozlowski MT, Manenti F, Pilotscale synthesis and rheological assessment of poly(methyl methacrylate) polymers: Perspectives for medical application. Mater Sci Eng C. 2015; 51: 107-116.

21. Lima NMN, Zuniga LL, Manenti F, Maciel Filho R, Wolf Maciel MR, Embiruçu M, Novel two-steps optimal control of batch polymerization reactors and application to PMMA production for the fabrication of artificial bone tissue. In: Kraslawski A, Turunen I (Eds). ESCAPE 23- European Symposium of Computer Aided Process Engineering: Proceeding of ESCAPE 23, European Symposium of Computer Aided Process Engineering; June 9-12, 2013; Lappeeranta-Finland. Amsterdam: Elsevier, 2013. 163-168.

22. Zuniga LL, Bonon A, Lima NMN, Maciel Filho R, Manenti F, Quality control of Poly(methyl methacrylate) to medical purpose by multiple headspace extraction, Chem Eng Trans. 2013; 32:1699-1705.

23. Freshney R.I. Culture of animal cells, fifth ed. New York: John Wiley \& Sons, Inc., 2005

24. Ekwall, B., Silano, V., Paganuzzi-Stammati, A., Zucco, F. Toxicity tests with mammalian cell cultures. In: Short-term Toxicity Tests for Non-genotoxic Effects. New York: John Wiley \& Sons, Inc, 1990. p. 75-97.

25. Mosmann T. Rapid colorimetric assay for cellular growth and survival: application to proliferation and cytotoxicity assays, J. Immunol Methods. 1983; 65: 55-63.

26. Molecular Probes, product information, LIVE/DEAD Viability/Cytotoxicity kit *for mammalian cells*. 2005. MP03224. Available from //https://tools.lifetechnologies.com/content/sfs/manuals/mp03224.pdf, 